\title{
ANALISIS PENGARUH SISTEM PENGENDALIAN INTERN DAN IMPLEMENTASI SISTEM AKUNTANSI KEUANGAN DAERAH (SAKD) TERHADAP KUALITAS LAPORAN KEUANGAN PEMERINTAH DAERAH (STUDI EMPIRIS PADA SKPD KOTA MANADO)
}

\author{
Gyshella Smylie Lumintang ${ }^{1}$, Linda Lambey ${ }^{2}$, Steven J. Tangkuman ${ }^{3}$ \\ ${ }^{1,2,3}$ Fakultas Ekonomi dan Bisnis, Jurusan Akuntansi, Universitas Sam Ratulangi, Jl. Kampus Bahu, Manado, \\ 95115, Indonesia \\ E-mail : gyshellalumintang@ymail.com
}

\begin{abstract}
Local government financial statement made to provide information about financial position and all transactions conducted by local government. A qualified local government financial statement must have relevant, reliable, comparable and understandable characteristics. There are several factors that may affect the quality of local government financial statements, that is, internal control system and financial accounting system of local government. This research was aimed to determine the effect of internal control system and financial accounting system of local government to the quality of financial statements at the local government of Manado City. Respondents of this research were 40 financial management personnel from 10 Manado City SKPD from 168 population of financial management personnel of Manado City SKPD. This research used a quantitative approach, using primary data through questionnaires. The variables in this research is the internal control system and financial accounting system of local government as the independent variables and the quality of local government financial statement as the dependent variable. The data collected were processed using SPSS version 23.0. The statistical methods used to test the hypotheses is multiple linear regression analysis. The results of hypothesis shown that the internal control system has a significant positive effect on the quality of Manado City local government financial statement while the implementation of financial accounting system of local government has no significant positive effect on the quality of Manado City local government financial statements and internal control system and financial accounting system of local government has a significant positive effect on the quality of Manado City local government financial statement.
\end{abstract}

Keywords : Internal control system, financial accounting system of local government, financial accounting system of local government

\section{PENDAHULUAN}

Organisasi sektor publik adalah sebuah entitas ekonomi yang menyediakan barang dan/atau jasa publik untuk meningkatkan kesejahteraan masyarakat dan bukan untuk mencari keuntungan finansial (Nordiawan \& Hertianti, 2010). Dengan pola pikir masyarakat yang semakin berkembang, tuntutan transparansi dan akuntabilitas pengelolaan sumber daya yang dipercayakan rakyat kepada organisasi sektor publik semakin menguat di Indonesia, baik di pusat maupun daerah. Transparansi adalah prinsip yang menjamin akses atau kebebasan bagi setiap orang untuk memperoleh informasi tentang penyelenggaraan pemerintahan, yakni informasi tentang kebijakan proses pembuatan dan pelaksanaanya serta hasil-hasil yang dicapai. Akuntabilitas publik adalah kewajiban agen (pemerintah) untuk mengelola sumber daya, melaporkan, dan mengungkapkan segala aktivitas dan kegiatan yang berkaitan dengan penggunaan sumber daya publik kepada pemberi mandat (prinsipal) (Mahmudi, dikutip dalam Merialsa, 2017). 
Laporan Keuangan Pemerintah Daerah (LKPD) sebagai perwujudan pertanggungjawaban keuangan pemerintah daerah setiap tahunnya mendapat penilaian berupa opini atas kewajaran informasi keuangan dari Badan Pengawas Keuangan (BPK) . Terdapat empat opini yang diberikan pemeriksa yaitu : Opini Wajar Tanpa Pengecualian (WTP), Opini Wajar Dengan Pengecualian (WDP), Opini Tidak Wajar (TP), dan Pernyataan Menolak memberi Opini atau Tidak Memberi Pendapat (TMP). Dalam Ikhtisar Hasil Pemeriksaan Semester (IHPS) II LKPD 2015, Badan Pemeriksa Keuangan (BPK) melakukan pemeriksaan terhadap 533 Laporan Keuangan Pemerintah Daerah (LKPD) dari 542 pemerintah daerah yang wajib menyusun laporan keuangan, BPK mencatat hanya 312 pemerintah daerah yang mendapatkan opini wajar tanpa pengecualian (WTP). Dalam pemeriksaan LKPD tahun 2015, BPK memberikan opini WTP atas 312 LKPD atau sebesar 58\%, selanjutnya 187 LKPD mendapatkan opini Wajar Dengan Pengecualian (WDP) atau 35\%. Kemudian ada 30 LKPD atau 6\% yang mendapatkan opini Tidak Memberikan Pendapat (TMP) dari BPK dan 4 LKPD mendapatkan opini Tidak Wajar (TW) atau 1\% (www.bpk.go.id - IHPS II 2015). Melalui data BPK ini diketahui masih banyaknya masalah dalam pelaporan keuangan pemerintah daerah, dimana belum seluruh laporan keuangan pemerintah yang mendapatkan opini Wajar Tanpa Pengecualian (WTP). Hal ini berarti masih banyaknya penyimpangan-penyimpangan yang ditemukan dalam penyusunan laporan keuangan pemerintah daerah. Permasalahan laporan keuangan lainnya dari pemerintah pusat ialah ketidaksesuaian dengan standar akuntansi pemerintahan, kelemahan sistem pengendalian intern dan ketidakpatuhan terhadap ketentuan peraturan perundang-undangan.

Bersangkutan dengan masalah pelaporan keuangan dan nilai informasi yang terkandung dalam laporan keuangan pemerintah yang menimbulkan pertanyaan apakah pelaporan keuangan pemerintah selama ini sudah memenuhi kriteria kecukupan informasi yang disyaratkan undang-undang? Benarkah laporan keuangan pokok yang terdiri dari Laporan Realisasi Anggaran, Laporan Perubahan Saldo Anggaran Lebih, Neraca, Laporan Operasional, Laporan Arus Kas, Laporan Perubahan Ekuitas dan Catatan atas Laporan Keuangan (PP No 71 Tahun 2010) di Pemerintah Daerah di Indonesia telah relevan, andal, dapat dibandingkan, dan dapat dipahami?

Faktor yang mungkin berpengaruh pada Laporan Keuangan adalah Sistem pengendalian intern (SPI) menurut Peraturan Pemerintah Nomor 60 Tahun 2008 SPI adalah proses yang integral pada tindakan dan kegiatan yang dilakukan secara terus menerus oleh pimpinan dan seluruh pegawai untuk memberikan keyakinan memadai atas tercapainya tujuan organisasi melalui kegiatan yang efektif dan efisien, keandalan pelaporan keuangan, pengamanan aset negara, dan ketaatan terhadap peraturan perundang-undangan. Hal selanjutnya yang mungkin memiliki andil dalam memengaruhi kualitas laporan keuangan pemerintah daerah adalah implementasi Sistem Akuntansi Keuangan Daerah (SKAD), Sistem Akuntansi Keuangan Daerah yaitu serangkaian prosedur mulai dari proses pengumpulan data, pencatatan, pengikhtisaran, sampai dengan pelaporan keuangan, dalam rangka pertanggungjawaban pelaksanaan APBD yang dapat dilakukan secara manual atau menggunakan komputer (Permendagri No. 59 Tahun 2007).

\section{TINJAUAN PUSTAKA}

\subsection{Landasan Teori}

\subsubsection{Agency Theory}

Di sektor publik, teori keagenan dipergunakan untuk menganalisis sumber prinsipal agen dalam kaitannya dalam penganggaran sektor publik (Latifah, 2010; Abdullah, 2012 dalam Parawati, 2015).

\subsubsection{Pemerintah Daerah}


Menurut Undang-Undang Nomor 23 Tahun 2014 tentang Pemerintah Daerah, Pemerintah Daerah merupakan kepala daerah sebagai unsur penyelenggara Pemerintahan Daerah yang memimpin pelaksanaan urusan pemerintahan yang menjadi kewenangan daerah otonom.

\subsubsection{Laporan Keuangan}

Menurut PSAK No. 1 (2009) Laporan keuangan adalah penyajian terstruktur dari posisi keuangan dan kinerja keuangan suatu entitas.

\subsubsection{Kualitas Laporan Keuangan Pemerintah Daerah}

Karakteristik kualitatif yang sebagaimana disyaratkan dalam Peraturan Pemerintah No. 71 Tahun 2010 tentang Standar Akuntansi Pemerintahan, yakni:

1. Relevan

Informasi dikatakan relevan apabila informasi yang termuat di dalamnya dapat mempengaruhi keputusan pengguna dengan membantu mereka mengevaluasi peristiwa masa lalu atau masa kini dan memprediksi masa depan, serta mengoreksi hasil evaluasi mereka di masa lalu. Informasi yang relevan memiliki unsur-unsur berikut :

\section{Andal}

a. Manfaat umpan balik (feedback value).

b. Manfaat prediktif (predictive value).

c. Tepat waktu (timeliness).

d. Lengkap

Keandalan informasi sangat bergantung pada kemampuan suatu informasi dalam menyajikan secara wajar keadaan atau peristiwa yang disajikan dengan keadaan yang sebenarnya terjadi. Keandalan suatu informasi akan berbeda, tergantung pada level pemakai, tingkat pemahaman pada aturan dan standar yang digunakan untuk menyajikan informasi tersebut. Suatu informasi dikatakan andal apabila :
a. Dapat diuji kebenarannya (verifiable)
b. Netral
c. Penyajian secara wajar/ jujur (representational faithfulness)

\section{Dapat dibandingkan}

Informasi yang termuat dalam laporan keuangan akan lebih berguna jika dapat dibandingkan dengan laporan keuangan periode sebelumnya atau laporan keuangan entitas pelaporan lain pada umumnya.

4. Dapat dipahami

Informasi yang disajikan dalam laporan keuangan dapat dipahami oleh pengguna dan dinyatakan dalam bentuk serta istilah yang disesuaikan dengan batas pemahaman para pengguna.

\subsubsection{Sistem Pengendalian Intern}

Sistem pengendalian intern (SPI) menurut Peraturan Pemerintah Nomor 60 Tahun 2008 adalah proses yang integral pada tindakan dan kegiatan yang dilakukan secara terus menerus oleh pimpinan dan seluruh pegawai untuk memberikan keyakinan memadai atas tercapainya tujuan organisasi melalui kegiatan yang efektif dan efisien, keandalan pelaporan keuangan, pengamanan aset negara, dan ketaatan terhadap peraturan perundang-undangan.

Unsur-unsur sistem pengendalian intern pemerintah berdasarkan PP No. 60 tahun 2008 (BPKP), adalah sebagai berikut:

1. Lingkungan pengendalian

2. Penilaian resiko

3. Kegiatan pengendalian

4. Informasi dan komunikasi

5. Pemantauan pengendalian intern

\subsubsection{Sistem Akuntansi Keuangan Daerah (SAKD)}


Sistem Akuntansi Keuangan Daerah (SAKD) adalah serangkaian prosedur mulai dari proses pengumpulan data, pencatatan, pengikhtisaran, sampai dengan pelaporan keuangan dalam rangka pertanggungjawaban pelaksanaan APBD yang dapat dilakukan secara manual atau menggunakan aplikasi komputer (Permendagri No. 59 Tahun 2007). Menurut Gade (2000) Sistem Akuntansi Pemerintah Daerah adalah sistem akuntansi yang mengolah semua transaksi keuangan, aset, kewajiban, dan ekuitas pemerintah yang menghasilkan informasi laporan keuangan yang tepat waktu dengan mutu yang dapat diandalkan, baik yang diperlukan oleh badan-badan diluar eksekutif, maupun oleh berbagai tingkatan manajemen pada pemerintahan.

\subsection{Penelitian Terdahulu}

Dewi Andini dan Yusrawati (2015) dalam penelitian berjudul pengaruh kompetensi sumber daya manusia dan penerapan sistem akuntansi keuangan daerah terhadap kualitas laporan keuangan daerah menunjukan hasil penerapan sistem akuntansi keuangan daerah berpengaruh signifikan terhadap kualitas laporan keuangan daerah.

As Syifa Nurilah (2014) dalam penelitian berjudul Pengaruh Kompetensi Sumber Daya Manusia, penerapan sistem akuntansi keuangan daerah (SAKD), Pemanfaatan teknologi informasi, dan sistem pengendalian intern terhadap kualitas laporan keuangan pemerintah daerah mendapatkan hasil kompetensi SDM, penerapan sistem akuntansi keuangan daerah, pemanfaatan teknologi informasi dan sistem pengendalian intern pemerintah mempunyai pengaruh positif dan signifikan.

\subsection{Hipotesis Penelitian}

H1 : $\quad$ Sistem Pengendalian Intern berpengaruh signifikan positif terhadap

Kualitas Laporan Keuangan Pemerintah Daerah.

H2 : Sistem Akuntansi Keuangan Daerah berpengaruh signifikan positif terhadap kualitas laporan keuangan pemerintah daerah.

H3 : Sistem Pengendalian Intern dan Sistem Akuntansi Keuangan Daerah secara simultan berpengaruh signifikan positif terhadap Kualitas Laporan Keuangan Daerah.

\section{METODE PENELITIAN}

\subsection{Jenis Penelitian}

\subsection{Tempat Dan Waktu Penelitian}

Penelitian ini dilakukan di Kota Manado dengan objek penelitian pegawai keuangan di beberapa SKPD Kota Manado. Tempat penelitian adalah 10 SKPD pada Pemerintah Kota Manado. Waktu penelitian dimulai dari bulan Agustus -September 2017.

\subsection{Prosedur Penelitian}

Penulis melakukan kajian awal dengan melakukan studi literatur baik studi kepustakaan maupun membaca di internet. Kemudian melakukan pengidentifikasian masalah, merumuskannya, menetapkan tujuan/manfaat penelitian, kemudian membatasi masalah ke lingkup yang disesuaikan dengan penelitian saat ini. Perancangan dan persiapan survey pada objek penelitian yang telah ditentukan, kemudian pengumpulan data baik primer melalui kuisioner kepada pegawai keuangan di beberapa SKPD Kota Manado maupun data sekunder. Melakukan pengolahan data, membahasnya kemudian menarik kesimpulan dan memberikan saran-saran guna melengkapi penelitian.

\subsection{Populasi dan Sampel}

\subsubsection{Populasi Penelitian}

Populasi adalah seluruh data yang menjadi perhatian peneliti dalam suatu ruang lingkup, dan waktu yang sudah ditentukan (Kasmadi \& Sunariah, 2016 : 65). Populasi dalam hal ini adalah pegawai bagian keuangan Perangkat Daerah Kota Manado yang terdiri dari 1 
Sekretariat Daerah, 1 Sekretariat DPRD, 1 Inspektorat, 22 Dinas, 6 Badan dan 11 Kecamatan. Dengan total 42 Perangkat Daerah dengan masing-masing SKPD memiliki 4 pegawai bagian keuangan yaitu, Kasubag Keuangan, Bendahara Pengeluaran/Penerimaan, Operator Simda Keuangan, Pembantu Bendahara dengan total 168 pegawai bagian keuangan sebagai populasi.

\subsubsection{Sampel Penelitian}

Menurut Sugiyono (dikutip dalam Kasmadi \& Sunariah, 2016 : 66) Sampel adalah sebagian dari jumlah dan karakteristik yang dimiliki oleh populasi tersebut. Sampel atas responden dilakukan secara purposive sampling. Purposive sampling digunakan karena informasi yang akan diambil berasal dari sumber yang sengaja dipilih berdasarkan kriteria yang telah ditetapkan yaitu pegawai bagian keuangan SKPD Kota Manado.

Penentuan responden dengan jumlah 40 sampel untuk 10 SKPD yang akan diteliti dari total 168 populasi dari 42 SKPD Kota Manado. Dengan pemilihan 40 sampel ini diharapkan telah memenuhi persepsi para pegawai keuangan SKPD Kota Manado.

\subsection{Metode Pengumpulan Data}

\subsubsection{Jenis Data}

Jenis Data yang digunakan dalam penelitian ini adalah jenis data kuantitatif.

\subsubsection{Sumber Data}

Sumber data dalam penelitian ini adalah data primer yang merupakan data penelitian yang diperoleh langsung dari sumbernya. Peneliti memperoleh data primer menggunakan survey kuisioner. Kuisioner ini disampaikan kepada 40 pegawai bagian keuangan PD Kota Manado.

\subsubsection{Teknik Pengumpulan Data}

Metode pengumpulan data yang digunakan dalam penelitian ini adalah sebagai berikut:

1. Mengumpulkan informasi yang berhubungan dengan judul penelitian dan masalah yang bisa diangkat menjadi bahan penelitian, baik media cetak maupun lewat internet serta lewat karya tulis ilmiah lainnya.

2. Memperoleh gambaran umum dari objek penelitian yang tepat secara keseluruhan serta mengetahui permasalahan yang ada.

3. Mengolah data yang diperoleh dimana peneliti membagikan kuisioner berupa daftar pertanyaan kepada responden, dalam hal ini pegawai bagian keuangan SKPD.

4. Menarik kesimpulan dan memberikan saran yang dianggap perlu sebagai perbaikan dalam permasalahan yang ada.

\subsection{Metode Analisis Data}

Metode analisis data yang digunakan dalam penelitian ini adalah analisis regresi linier berganda (Multiple Regression Analysis) dengan bantuan program Statistical Product and Service Solution (SPSS). Analisis ini dimaksudkan untuk mengungkapkan pengaruh antara beberapa variabel bebas dengan variabel terikat.

\subsection{Hipotesis Statistik}

1. Ho: $\beta 1=0$ : Tidak terdapat pengaruh yang signifikan positif antara sistem pengendalian intern terhadap kualitas laporan keuangan pemerintah daerah.

H1: $\beta 1 \neq 0 \quad$ : $\quad$ Terdapat pengaruh yang signifikan positif antara sistem pengendalian intern terhadap kualitas laporan keuangan pemerintah daerah.

2. Ho: $\beta 2=0$ : Tidak terdapat pengaruh yang signifikan positif antara sistem akuntansi keuangan daerah terhadap kualitas laporan keuangan pemerintah daerah. 


\begin{tabular}{lll}
\hline H1: $\beta 2 \neq 0 \quad: \quad$ & $\begin{array}{l}\text { Terdapat pengaruh yang signifikan positif antara } \\
\text { sistem akuntansi keuangan daerah terhadap kualitas } \\
\text { laporan keuangan pemerintah daerah. }\end{array}$ \\
& Tidak terdapat pengaruh yang signifikan positif \\
& antara sistem pengendalian intern dan sistem \\
& akuntansi keuangan daerah terhadap kualitas \\
& laporan keuangan pemerintah daerah. \\
& Terdapat pengaruh yang signifikan positif antara \\
& sistem pengendalian intern dan sistem akuntansi
\end{tabular}

\subsection{Definisi dan Pengukuran Variabel}

a. Variabel Dependen

1) Kualitas Laporan Keuangan

Menurut Standar Akuntansi Keuangan yang dikeluarkan oleh Ikatan Akuntan Indonesia 2009, tujuan laporan keuangan adalah menyediakan informasi yang menyangkut posisi keuangan, kinerja, serta perubahan posisi keuangan suatu perusahaan yang bermanfaat bagi sejumlah besar pemakai dalam pengambilan keputusan. Informasi akuntansi yang terdapat di dalam laporan keuangan pemerintah daerah harus memenuhi beberapa karakteristik kualitatif yang sebagaimana disyaratkan dalam Peraturan Pemerintah No. 24 Tahun 2005 tentang Standar Akuntansi Pemerintahan, yakni:

Relevan, andal, dapat dibandingkan dan dapat dipahami.

Variabel kualitas laporan keuangan pemerintah daerah diukur dengan instrumen penelitian Soimah (2014).

2) Variabel Independen

\section{1) Sistem Pengendalian Intern}

Pada Tahun 2008, Pemerintah mengeluarkan Peraturan Pemerintah Nomor 60 Tahun 2008 tentang Sistem Pengendalian intern Pemerintah (SPIP). Dalam PP tersebut menyebutkan bahwa tujuan SPIP bertujuan untuk memberikan keyakinan yang memadai bagi tercapainya:

a. efektivitas dan efisiensi pencapaian tujuan penyelenggaraan pemerintahan negara;

b. keandalan Laporan Keuangan;

c. pengamanan aset negara; dan

d. ketaatan terhadap peraturan perundang-undangan.

Unsur-unsur sistem pengendalian intern pemerintah berdasarkan PP No. 60 tahun 2008 (BPKP), adalah sebagai berikut:

1. Lingkungan pengendalian

2. Penilaian resiko

3. Kegiatan pengendalian

4. Informasi dan komunikasi

5. Pemantauan pengendalian intern

Instrumen penelitian yang penulis gunakan untuk mengukur SPI adalah unsur-unsur SPI. Variabel sistem pengendalian intern diukur dengan instrumen penelitian Soimah (2014).

2) Sistem Akuntansi Keuangan Daerah

Sistem Akuntansi Keuangan Daerah (SAKD) yaitu serangkaian prosedur mulai dari proses pengumpulan data, pencatatan, pengikhtisaran, sampai dengan pelaporan keuangan, dalam rangka pertanggungjawaban pelaksanaan APBD yang dapat dilakukan secara manual atau menggunakan aplikasi komputer (Permendagri No. 59 Tahun 2007).

Sebagaimana pengertian tersebut instrumen pengukuran SAKD yang penulis gunakan adalah kesesuaian sistem akuntansi keuangan daerah dengan SAP dan pembuatan laporan keuangan yang dilaporkan secara periodik. Variabel sistem akuntansi keuangan daerah 
(SAKD) diukur dengan instrument penelitian soimah (2014) dan dimodifikasi dengan penambahan instrumen penelitian dari Permadi (2013).

\section{HASIL ANALISIS DAN PEMBAHASAN}

\subsection{Hasil Penelitian}

Dalam hasil penelitian akan dijelaskan mengenai deskripsi data, tingkat pengembalian kuesioner, gambaran umum responden, statistik deskriptif, hasil uji kualitas data, hasil uji asumsi dasar dan hasil uji asumsi klasik, serta hasil uji hipotesis.

\subsection{Statistik Deskriptif}

Tabel berikut menunjukkan hasil statistik deskriptif berdasarkan data yang diperoleh dari responden

\section{Statistik Deskriptif Responden}

\section{Descriptive Statistics}

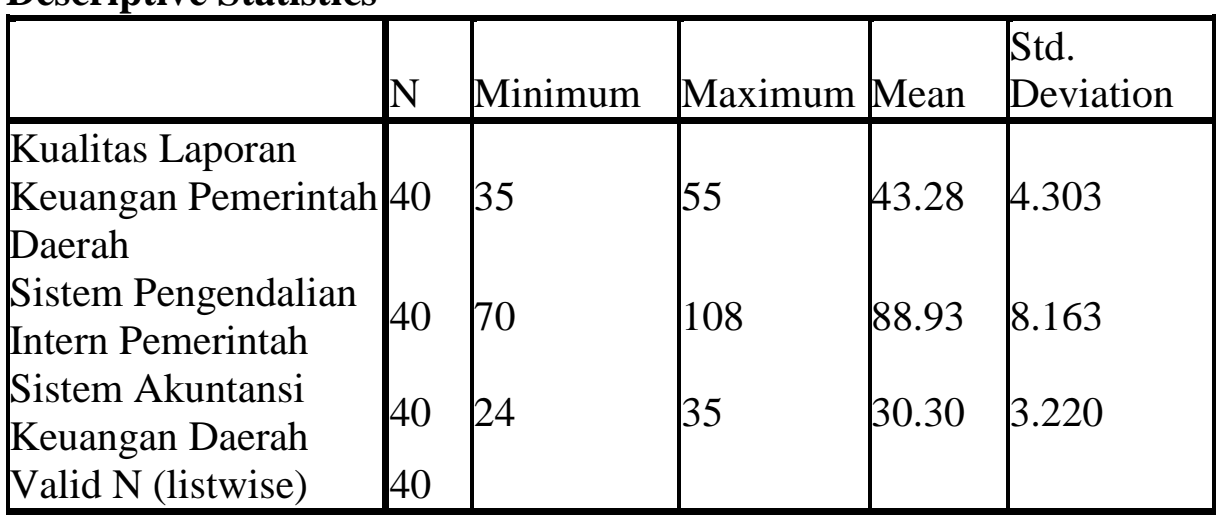

Sumber: data spss

Tabel berikut ini menunjukan hasil statistik deskriptif berdasarkan rata-rata distribusi jawaban responden untuk setiap instrument pertanyaan.

Rata- Rata Distribusi Frekuensi Jawaban Responden

\begin{tabular}{|c|c|c|c|c|c|c|c|c|c|c|c|}
\hline \multicolumn{12}{|c|}{$\begin{array}{c}\text { Laporan Keuangan Pemerintah Daerah (Y) } \\
\text { Pertanyaan Ke } \\
\end{array}$} \\
\hline & 1 & 2 & 3 & 4 & 5 & 6 & 7 & 8 & 9 & 10 & 11 \\
\hline $\begin{array}{l}\text { Rata- } \\
\text { rata }\end{array}$ & 3.92 & 3.82 & 4.10 & 4.12 & 4.05 & 3.57 & 3.62 & 4.10 & 3.90 & 3.97 & 4.02 \\
\hline \multicolumn{12}{|c|}{$\begin{array}{l}\text { Total } \\
\text { Rata-Rata: } \mathbf{3 . 9 2} \\
\end{array}$} \\
\hline \multicolumn{12}{|c|}{$\begin{array}{c}\text { Sistem Pengendalian Intern (X1) } \\
\text { Pertanyaan Ke }\end{array}$} \\
\hline & 1 & 2 & 3 & 4 & 5 & 6 & 7 & 8 & 9 & 10 & 11 \\
\hline \multirow[t]{3}{*}{$\begin{array}{l}\text { Rata- } \\
\text { rata }\end{array}$} & 3.90 & 3.95 & 4.17 & 3.95 & 4.05 & 3.90 & 4.20 & 3.97 & 4.10 & 3.90 & 4.02 \\
\hline & 12 & 13 & 14 & 15 & 16 & 17 & 18 & 19 & 20 & 21 & 22 \\
\hline & 4.27 & 3.97 & 4.05 & 4.00 & 4.02 & 4.32 & 4.02 & 3.95 & 3.95 & 4.1 & 4.12 \\
\hline
\end{tabular}




\begin{tabular}{|l|r|r|r|r|r|r|r|r|}
\hline \hline \multicolumn{10}{|l|}{ Total } \\
Rata-Rata : 4.04 \\
\hline \multicolumn{10}{|l|}{ Pertanyaan Ke } \\
\hline & 1 & 2 & 3 & 4 & 5 & 6 & 7.325 \\
\hline $\begin{array}{l}\text { Rata- } \\
\text { rata }\end{array}$ & 4.375 & 4.15 & 4.5 & 4.3 & 4.325 & 4.275 & \\
\hline $\begin{array}{l}\text { Total } \\
\text { Rata-Rata : 4.328 }\end{array}$ \\
\hline
\end{tabular}

Sumber : Data SPSS

\subsection{Hasil Uji Kualitas Data}

\subsubsection{Hasil Uji Validitas}

Hasil uji validitas menunjukkan Pearson Correlation untuk setiap variabel yaitu, Kualitas Laporan Keuangan Pemerintah Daerah (Y), Sistem Pegendalian Intern Pemeritah (X1), dan Sistem Akuntansi Keuangan Daerah (X2), signifikan pada tingkat signifikansi 0,05. Dengan demikian dapat disimpulkan bahwa semua pertanyaan dalam kuesioner mampu untuk mengukur variabel yang diharapkan.

\subsubsection{Hasil Uji Reliabilitas}

Uji reliabilitas diukur dengan uji statistik Cronbach's Alpha $(\alpha)$. Jika nilai Cronbach's Alpha $>$ 0,70 maka data dikatakan reliabel. Hasil pengujian reliabilitas dalam penelitian ini dapat terlihat pada tabel berikut :

Hasil Pengujian Reliabilitas

\begin{tabular}{|c|c|}
\hline \multicolumn{2}{|c|}{ Kualitas Laporan Keuangan Daerah } \\
(Y)
\end{tabular}

Sumber : Data Olahan SPSS 
Berdasarkan hasil pengujian reliabilitas pada tabel diatas, hasil perhitungan menunjukkan bahwa nilai Cronbach's Alpha $(\alpha)$ untuk setiap variabel adalah lebih besar dari 0,70. Dengan demikian, dapat disimpulkan bahwa pertanyaan untuk masing-masing variabel dikatakan reliabel.

\subsection{Hasil Uji Asumsi Dasar}

\subsubsection{Hasil Uji Normalitas}

Uji normalitas bertujuan untuk mengetahui apakah dalam model regresi, variabel independen dan variabel dependen mempunyai distribusi normal. Uji normalitas menggunakan Kolmograv-smirnov dengan nilai kolmograv-smirnov test > 0,05 (Ghozali, 2011). Hasil pengujian normalitas dapat dilihat dalam tabel berikut :

\section{Tabel 4.7}

Hasil Pengujian Normalitas

One-Sample Kolmogorov-Smirnov Test

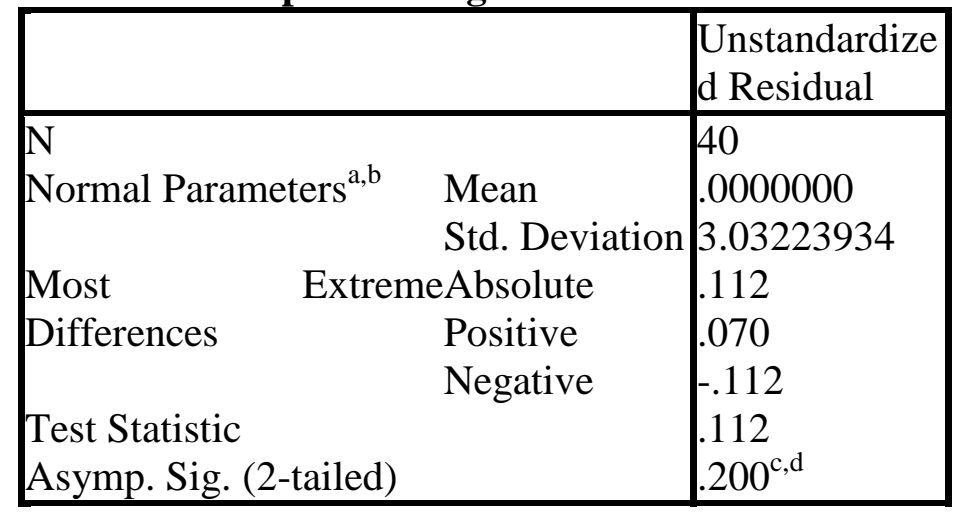

a. Test distribution is Normal.

b. Calculated from data.

c. Lilliefors Significance Correction.

$\mathrm{d}$. This is a lower bound of the true significance.

Sumber : Data SPSS

Dari tabel 4.7 menunjukan bahwa kolmograv-smirnov test $>0,05$ maka data berdistribusi secara normal.

\subsubsection{Hasil Uji Heteroskedastisitas}

Mendeteksi ada tidaknya heterokedastisitas dapat dilakukan dengan melihat ada tidaknya pola tertentu pada grafik scatterplot. Tidak terjadi heteroskedastisitas apabila tidak ada pola yang jelas, serta titik-titik menyebar di atas dan di bawah angka 0 pada sumbu Y (Imam Ghozali, 2013: 139-143). Berikut disajikan hasil uji heterokedastisitas yang dilakukan menggunakan program SPSS 23 :

Hasil Pengujian Heteroskedastisitas

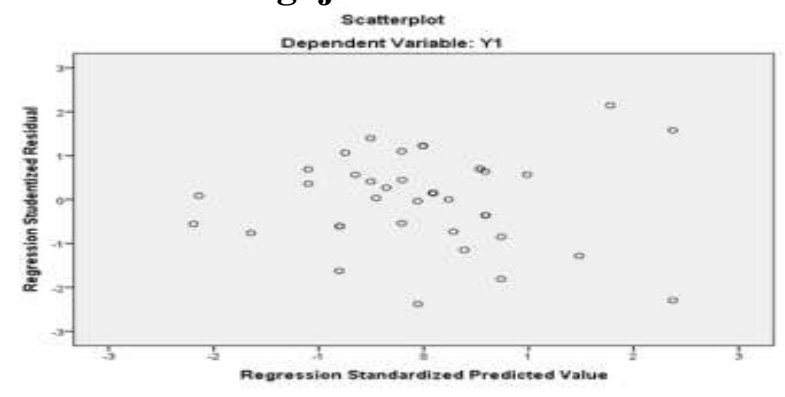


Berdasarkan gambar tersebut dapat disimpulkan bahwa tidak terjadi heterokedastisitas dan model regresi layak untuk dipakai, hal ini dibuktikan dengan tidak adanya pola yang jelas, serta titik-titik menyebar di atas dan dibawah angka 0 pada sumbu Y.

\subsection{Analisis Data}

Dalam penelitian ini data dianalisis dengan menggunakan metode analisis regresi berganda. Dengan bantuan program SPSS 23 didapatkan hasil sebagai berikut :

\section{Analisis Regresi}

Coefficients $^{\mathrm{a}}$

\begin{tabular}{|c|c|c|c|c|c|}
\hline \multirow[b]{2}{*}{ Model } & \multicolumn{2}{|c|}{$\begin{array}{c}\text { Unstandardized } \\
\text { Coefficients }\end{array}$} & \multirow{2}{*}{$\begin{array}{c}\text { Standardized } \\
\text { Coefficients } \\
\text { Beta } \\
\end{array}$} & \multirow[b]{2}{*}{$\mathrm{T}$} & \multirow[b]{2}{*}{ Sig. } \\
\hline & B & $\begin{array}{l}\text { Std. } \\
\text { Error }\end{array}$ & & & \\
\hline 1 (Constant) & 12.032 & 5.539 & & 2.172 & .036 \\
\hline $\mathrm{X} 1$ & .454 & .091 & .861 & 4.961 & .000 \\
\hline $\mathrm{X} 2$ & -.300 & .232 & -.225 & -1.294 & .204 \\
\hline
\end{tabular}

Berdasarkan tabel di atas maka persamaan regresi yang didapatkan adalah sebagai berikut: $\mathrm{Y}=12.032+0.454 \mathrm{X} 1-0.300 \mathrm{X} 2$

Persamaan regresi linier berganda diatas dapat diartikan bahwa:

1. Konstanta sebesar 12.032 menyatakan bahwa tanpa ada pengaruh dari ketiga variabel independen dan faktor lain, maka variabel kualitas laporan keuangan daerah (Y1) pada satuan kerja perangkat daerah Kota Manado adalah 12.032 .

2. Koefisien regresi variabel sistem pengendalian intern 0.454. Hal ini berarti bahwa setiap terjadi kenaikan SPI sebesar 1 maka akan meningkatkan kualitas laporan keuangan daerah sebesar 0.454 dengan asumsi variabel lain tetap.

3. Koefisien regresi penerapan sistem akuntansi keuangan daerah -0.300 (negatif). Hal ini berarti bahwa setiap terjadi kenaikan penerapan sistem akuntansi keuangan daerah sebesar 1 maka akan menurunkan kualitas laporan keuangan daerah sebesar 0.300 dengan asumsi variabel lain tetap.

\subsection{Koefisien Determinasi $\left(R^{2}\right)$}

Uji Koefisien Determinasi $\left(\mathbf{R}^{2}\right)$

\begin{tabular}{|c|c|c|c|c|}
\hline \multicolumn{5}{|c|}{ Model Summary } \\
\hline Model & $\mathrm{R}$ & $\begin{array}{c}\mathrm{R} \\
\text { Square }\end{array}$ & $\begin{array}{c}\text { Adjusted } \\
\text { R } \\
\text { Square }\end{array}$ & $\begin{array}{c}\text { Std. } \\
\text { Error of } \\
\text { the } \\
\text { Estimate }\end{array}$ \\
\hline 1 & $.709^{a}$ & .503 & .476 & 3.113 \\
\hline
\end{tabular}

a. Predictors: (Constant), X2, X1

b. Dependent Variable: Y1

Berdasarkan koefisien determinasi diketahui bahwa nilai adjusted $\mathrm{R}$ square sebesar 0 , 503, yang mengandung arti bahwa 50,3\% variasi besarnya kualitas laporan keuangan daerah bisa dijelaskan oleh variasi sistem pengendalian intern dan penerapan sistem akuntansi keuangan daerah. Sedangkan sisanya 49,7\% lainnya dijelaskan oleh variabel lain di luar model.

\subsection{Hasil Uji Hipotesis}


Untuk menguji pengaruh variabel independen yaitu, Sistem Pengendalian Intern Pemerintah (X1) dan Implementasi Sistem Akuntansi Keuangan Daerah (X2) terhadap variabel dependen yaitu, Kualitas Laporan Keuangan Pemerintah Daerah (Y) digunakan model regresi berganda. Hasil olah data dengan bantuan SPSS 23 dapat terlihat pada tabel berikut :

\subsubsection{Uji Statistik t (Pengujian Secara Parsial) \\ 4.7.1.1 Pengujian hipotesis pertama}

Berdasarkan hasil analisis regresi diatas (Tabel 4.9) dapat dilihat nilai signifikansi untuk Sistem Pengendalian Intern pemerintah sebesar 0.000 lebih kecil dari 0.05, jika nilai signifikan $\leq 0,05$ maka hipotesis diterima (koefisien regresi signifikan). Ini berarti secara parsial variabel independen tersebut mempunyai pengaruh yang signifikan terhadap variabel dependen (Ghozali 2013: 98). Dapat disimpulkan bahwa hipotesis Ho: $\beta 1=0$ ditolak dan hipotesis $\mathrm{H} 1: \beta 1 \neq 0$ diterima, yaitu terdapat pengaruh yang signifikan positif antara Sistem Pengendalian Intern terhadap Kualitas Laporan Keuangan Pemerintah Daerah.

\subsubsection{Pengujian hipotesis kedua}

Dari hasil analisis regresi (Tabel 4.9) diatas dapat dilihat bahwa nilai signifikansi untuk penerapan sistem akuntansi keuangan daerah sebesar 0.204 lebih besar dari 0.05 . Jika nilai signifikan > 0,05 maka hipotesis ditolak (koefisien regresi tidak signifikan). Ini berarti secara parsial variabel independen tidak mempunyai pengaruh secara signifikan terhadap variabel dependen (Ghozali 2013: 98), sehingga hipotesis H1: $\beta 2 \neq 0$ ditolak dan hipotesis Ho: $\beta 2=0$ diterima, yaitu tidak terdapat pengaruh yang signifikan positif antara implementasi sistem akuntansi keuangan daerah terhadap kualitas laporan keuangan pemerintah daerah.

\subsubsection{Uji Statistik F (Pengujian Secara Simultan)}

Uji Statistik F

ANOVA ${ }^{\mathrm{a}}$

\begin{tabular}{|c|c|c|c|c|c|}
\hline Model & $\begin{array}{c}\text { Sum of } \\
\text { Squares }\end{array}$ & Df & $\begin{array}{c}\text { Mean } \\
\text { Square }\end{array}$ & $\mathrm{F}$ & Sig. \\
\hline 1 Regression & 363.390 & 2 & 181.695 & 18.748 & $.000^{\mathrm{b}}$ \\
\hline Residual & 358.585 & 37 & 9.691 & & \\
\hline Total & 721.975 & 39 & & & \\
\hline
\end{tabular}

a. Predictors: (Constant), X1 (SPI), X2 (penerapan SAKD)

b. Dependent Variable: Y (kualitas laporan keuangan daerah)

\subsubsection{Pengujian hipotesis ketiga}

Dari tabel 4.10 dapat dilihat bahwa uji anova atau $\mathrm{F}$ test menghasilkan nilai signifikansi 0.000. Karena nilai signifikansi lebih kecil dari 0,05 maka hipotesis Ho: $\beta 1.2=0$ ditolak dan hipotesis $\mathrm{H} 1: \beta 1.2 \neq 0$ diterima, artinya secara simultan sistem pengendalian intern dan implementasi sistem akuntansi keuangan daerah berpengaruh signifikan positif terhadap kualitas laporan keuangan daerah.

\subsection{Pembahasan}

\subsubsection{Pengaruh Sistem Pengendalian Intern Terhadap Kualitas Laporan Keuangan Pemerintah Daerah}

Berdasarkan hasil pengujian hipotesis I, dapat dilihat nilai signifikansi untuk sistem pengendalian intern pemerintah sebesar 0.000 lebih kecil dari 0.05 , jika nilai signifikan $\leq$ 0,05 maka hipotesis diterima (koefisien regresi signifikan ). Ini berarti secara parsial variabel independen tersebut mempunyai pengaruh yang signifikan terhadap variabel dependen 
(Ghozali 2013: 98). Jadi, hipotesis Ho: $\beta 1=0$ ditolak dan hipotesis $\mathrm{H1}: \beta 1 \neq 0$ diterima yaitu terdapat pengaruh yang signifikan positif antara sistem pengendalian intern terhadap kualitas laporan keuangan pemerintah daerah. Dapat disimpulkan bahwa Sistem Pengendalian Intern pemerintah Kota Manado berpengaruh signifikan positif terhadap Kualitas Laporan Keuangan Pemerintah Daerah Kota Manado

\subsubsection{Pengaruh Implementasi Sistem Akuntansi Keuangan Daerah Terhadap Kualitas Laporan Keuangan Pemerintah Daerah}

Berdasarkan hasil pengujian hipotesis II dapat dilihat bahwa nilai signifikansi untuk penerapan sistem akuntansi keuangan daerah sebesar 0.204 lebih besar dari 0.05 , jika nilai signifikan > 0,05 maka hipotesis ditolak (koefisien regresi tidak signifikan). Ini berarti secara parsial variabel independen tidak mempunyai pengaruh secara signifikan terhadap variabel dependen (Ghozali 2013: 98), sehingga hipotesis H1: $\beta 2 \neq 0$ ditolak dan hipotesis Ho: $\beta 2=0$ diterima, yaitu tidak terdapat pengaruh yang signifikan positif antara implementasi sistem akuntansi keuangan daerah terhadap kualitas laporan keuangan pemerintah daerah. Maka dapat disimpulkan bahwa Implementasi Sistem Akuntansi Keuangan Daerah tidak berpengaruh signifikan positif terhadap Kualitas Laporan Keuangan Pemerintah Daerah Kota Manado.Pegawai yang dipercayakan bekerja sebagai pengelola keuangan pada SKPD Kota Manado hanya sebagian kecil yang berlatar belakang akuntansi, yaitu 30\% sedangkan sisanya $70 \%$ dari latar belakang non akuntansi, hal ini dapat berindikasi pada ketidakpahaman aparatur pengelola keuangan pemerintah mengenai pedoman pengelolaan laporan keuangan terkait. Melalui pembahasan diatas dapat disimpulkan, Kualitas Laporan Keuangan Pemerintah Daerah Kota Manado akan semakin baik bila diimbangi dengan Implementasi Sistem Akuntansi Keuangan Daerah yang baik jika didukung pula dengan pengetahuan akuntansi yang baik dari para pegawai pengelola keuangan SKPD Kota Manado.

\subsubsection{Pengaruh Sistem Pengendalian Intern dan Implementasi Sistem Akuntansi Keuangan Daerah (SAKD) Terhadap Kualitas Laporan Keuangan Pemerintah Daerah}

Dilihat dari hasil uji hipotesis III, karena nilai signifikansi lebih kecil dari 0,05, maka hipotesis Ho: $\beta 1.2=0$ ditolak dan hipotesis $H 1: \beta 1.2 \neq 0$ diterima artinya secara simultan sistem pengendalian intern dan implementasi sistem akuntansi keuangan daerah berpengaruh signifikan positif terhadap kualitas laporan keuangan daerah. Kesimpulan dari penelitian ini berarti penerapan sistem pengendalian intern jika diimplementasikan dengan sistem akuntansi keuangan daerah secara bersama-sama akan mewujudkan laporan keuangan pemerintah daerah yang semakin berkualitas.

\section{KESIMPULAN DAN SARAN}

\subsection{Kesimpulan}

Penelitian ini bertujuan untuk mengetahui pengaruh penerapan Sistem Pengendalian Intern dan implementasi Sistem Akuntansi Keuangan Daerah (SAKD) terhadap kualitas Laporan Keuangan Pemerintah Daerah Kota Manado. Berdasarkan hasil penelitian, maka kesimpulan dari penelitian ini dapat diuraikan sebagai berikut:

1. Sistem pengendalian intern berpengaruh signifikan positif terhadap kualitas laporan keuangan pemerintah daerah Kota Manado, artinya bahwa semakin baik pelaksanaan unsur SPI maka semakin baik pula kualitas laporan keuangan pemerintah daerah yang dihasilkan.

2. Sistem Akuntansi Keuangan Daerah tidak berpengaruh signifikan positif terhadap kualitas laporan keuangan pemerintah daerah Kota Manado. Jika sistem akuntansi keuangan daerah kota manado telah sesuai dengan standar akuntansi keuangan dan dilaporkan secara periodik dijalankan dengan maksimal, serta dibekali dengan 
pengetahuan akuntansi yang mumpuni maka akan tercipta kualitas laporan keuangan yang baik pula.

3. Secara simultan sistem pengendalian intern dan implementasi sistem akuntansi keuangan daerah berpengaruh signifikan positif terhadap kualitas laporan keuangan daerah artinya bahwa penerapan sistem pengendalian intern jika diimplementasikan dengan sistem akuntansi keuangan daerah secara bersama-sama akan mewujudkan laporan keuangan pemerintah daerah yang semakin berkualitas.

\subsection{Saran}

1. Peneliti selanjutnya diharapkan untuk bisa mendapatkan data secara keseluruhan dari semua dinas/badan/kantor yang ada, agar hasil yang didapat lebih maksimal.

2. Untuk penelitian selanjutnya dapat melengkapi metode penelitian dengan menggunakan daftar pertanyaan dan melakukan wawancara langsung

3. Penelitian selanjutnya dapat dilakukan dengan menambahkan variabel lain yang tidak masuk dalam penelitian ini.

\section{DAFTAR PUSTAKA}

Ghozali, Imam. 2013. Aplikasi Analisis Multivariate dengan Program SPSS. Edisi

Ketujuh. Semarang : Universitas Diponegoro.

Ikatan Akuntan Indonesia, 2009. Standar Akuntansi Keuangan, PSAK No.1: $\quad$ Penyajian

Laporan Keuangan. Jakarta : Salemba Empat.

Kasmadi dan Nia Siti Sunariah. 2016. Panduan Modern Penelitian Kuantitatif. Bandung : Alfabeta.

Merialsa, Asmara Intan. 2017. Pengaruh Akuntabilitas Publik Dan Transparansi Terhadap

Kualitas Laporan Keuangan (Studi pada Inspektorat dan BPKAD Kota Bandung).

Bandung : Universitas Pasundan

Nordiawan, Deddi dan Ayuningtyas Hertianti. 2010. Akuntansi Sektor Publik, $\quad$ Edisi 2. Jakarta: Salemba Empat.

Parawati, Sayu Made. 2015. Perilaku Oportunistik Penyusun Anggaran. Bandung: Universitas Udayana.

Peraturan Pemerintah Nomor 60 Tahun 2008 tentang Sistem Pengendalian Intern

Permendagri No. 59 Tahun 2007 tentang Sistem Akuntansi Keuangan Daerah

PP No 71 Tahun 2010 tentang Standar Akuntansi Pemerintah

Undang-Undang Nomor 23 Tahun 2014 tentang Pemerintah Daerah 